\title{
Camillo Negro and his contributions to neurology
}

\author{
Camillo Negro e suas contribuições à Neurologia \\ Beatriz Gioppo BETINI'1, Alex Tiburtino MEIRA', Hélio Afonso Ghizoni TEIVE'
}

\begin{abstract}
An historical review of the contributions made by Italian professor, Camillo Negro, to neurology. Negro published several books on clinical neurology, was one of the pioneers of scientific films and described numerous neurological diseases. He is best known for describing the cogwheel phenomenon in patients with Parkinson's disease but also described a sign of peripheral facial paralysis.
\end{abstract}

Keywords: Neurology, history; muscular rigidity.

RESUMO

Os autores apresentam uma revisão histórica sobre as contribuições do Professor italiano Camilo Negro para à neurologia. Negro publicou vários livros sobre clínica neurológica e também foi um dos pioneiros na realização de filmes científicos, com a descrição de inúmeras doenças neurológicas. Ele é mais conhecido pela descrição do fenômeno da roda denteada em pacientes com a doença de Parkinson, mas também descreveu um sinal da paralisia facial periférica.

Palavras-chave: Neurologia, história; rigidez muscular.

Camillo Negro (Biella, 1861 - Torino, 1927) was an Italian neurologist and neuropathologist (Figure). In 1884, he graduated in medicine from the University of Turin, having been mentored by two of the most important professors of the time: the physiologist, Angelo Mosso, and the clinician, Camillo Bozzolo ${ }^{1}$. Negro had been Mosso's assistant in 1883 and became interested in neurology while working in his physiology laboratory ${ }^{2}$. At that time, the French, English and German schools of medicine were being established, laying the basis for modern neurology ${ }^{3}$. Spurred by his interest in neuropathology and the absence of a true Italian school in this discipline, Negro decided to migrate, moving to Heidelberg, Germany, in October 1884, where he remained until 1887. He attended the neurology clinic run by Wilhelm Heinrich Erb and the physiology laboratory run by Wilhelm Kühne, both of whom were pioneers in neurology at the time. During his stay in Germany, Negro's interest in clinical neuropathology grew and he embraced new fields of research, mainly related to neurophysiology and electrotherapy, which were still completely unknown in Italy ${ }^{2,4}$. On his return to his native country, he began to provide a free counseling service for patients with neuropathological conditions at the Policlinico Umberto I general hospital in Rome, an activity he was to continue until his death ${ }^{2}$. The culmination of his academic career was his appointment, in 1919, to the post of Director of the Neuropathology Clinic at the University of Turin ${ }^{2}$. In addition to his intense academic activity, Negro was one of the founders of the Italian Society of Neurology, created in Rome in 1907, and of which he was vice president from 1909 to $1911^{2}$. During World War I, Negro worked as a volunteer for the Turin military hospital, where he gained useful insights that helped his study of neurological pathologies in soldiers returning from war $^{1,2}$. He died in Turin on October 16, $1927^{2}$.

\section{NEGRO'S CONTRIBUTIONS TO NEUROLOGY}

Negro authored more than 150 studies and clinical notes and made many original contributions to the field of neurology. He was a passionate teacher, as attested by his students and his educational text, Patologia e Clinica del Sistema Nervoso: Lezioni del Prof. Camillo Negro ${ }^{5}$, in which he presented original observations on physiology, histology

\footnotetext{
1Universidade Federal do Paraná, Hospital de Clínicas, Departamento de Clínica Médica, Serviço de Neurologia, Curitiba PR, Brasil.

Beatriz Gioppo Betini (iD https://orcid.org/0000-0002-3714-6471; Alex Tiburtino Meira iD https://orcid.org/0000-0002-6685-7491; Hélio Afonso Ghizoni Teive (iD) https://orcid.org/0000-0003-2305-1073

Correspondence: Hélio A. G. Teive; Rua General Carneiro 1103/102, Centro; 80060-150 Curitiba PR, Brasil; E-mail: hagteive@mps.com.br

Conflict of interest: There is no conflict of interest to declare.

Received 07 November 2018; Accepted 15 January 2019.
} 


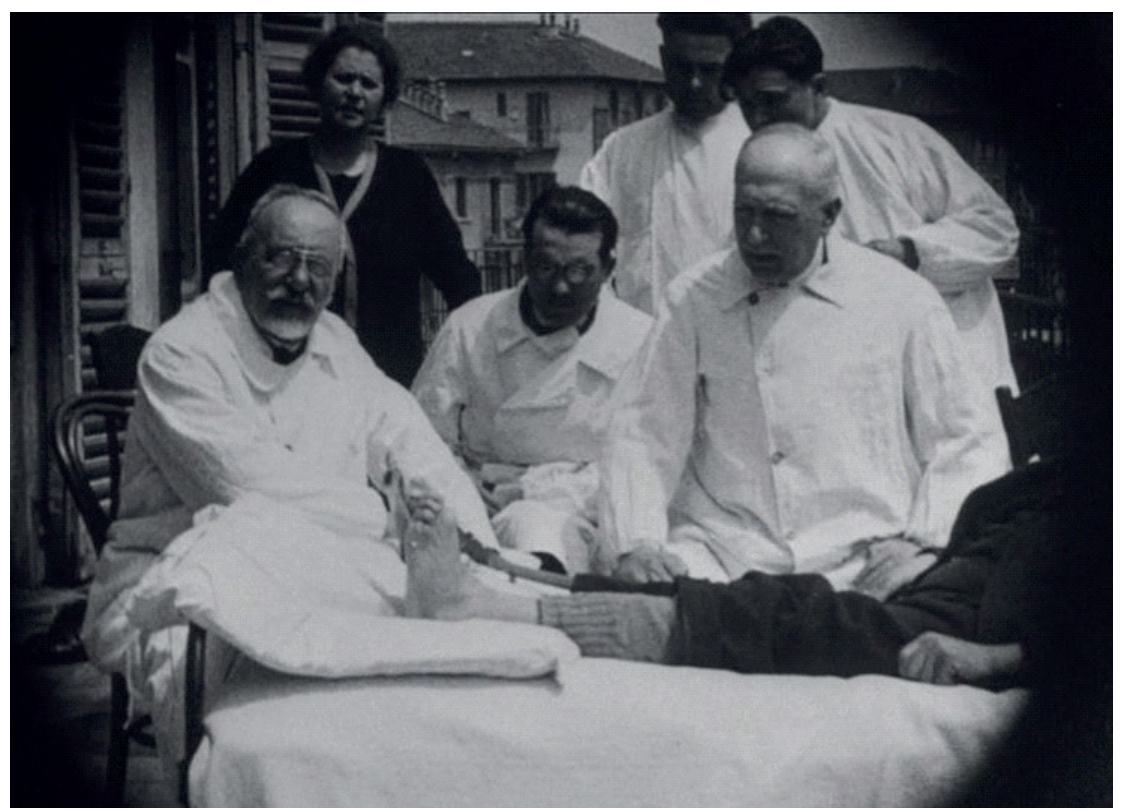

Figure. Professor Camillo Negro (left - white arrow) examining a patient in footage from one of his films. Extracted from: http:// www2. museocinema.it/restauri/muti_restaurati.php?id=139\&l=en [accessed in November $7^{\text {th }}, 2018$ ].

and pathophysiology. Cogwheel rigidity and Negro’s sign, associated with idiopathic Parkinson's disease and peripheral facial palsy, respectively, are also claimed to have been first described by him ${ }^{2,5}$. In 1817, Sir James Parkinson, in his handbook Essay on the Shaking Palsy, described a new disease that he called paralysis agitans ${ }^{6}$. During the $19^{\text {th }}$ century, the clinical features of this disease were further clarified, most notably by Jean-Martin Charcot, who suggested the name "Parkinson's disease" ${ }^{\text {", } 7,8}$. During the first two decades of the $20^{\text {th }}$ century, Camillo Negro (1901), Harold N. Moyer (1911) and Roberto Nóvoa Santos (1921), apparently unaware of each other's work, described cogwheel rigidity. This sign is one of the cardinal diagnostic criteria for parkinsonism and is often an early sign of Parkinson's disease ${ }^{6,7,89}$. Clinically, it is characterized by muscle stiffness throughout the range of passive movement in both extension and flexion. The hypertonicity is interrupted regularly, like a cogwheel mechanism, at a frequency of 6-9 Hz, which is higher than that of resting tremor $(4-5 \mathrm{~Hz})$ and postural tremor $(5-6 \mathrm{~Hz})^{9,10}$. The degree of rigidity does not depend on stretch velocity and persists as long as the stretch is maintained. According to one pathophysiological theory, the rigidity is due to dysfunction in segmental spinal circuits resulting in hyperactivity and hyperexcitability in long loop reflex pathways. Other structures probably involved in this process are the reticular nuclei and spinal interneurons $^{9,10}$. Negro and his coworker, the physiologist Zaccaria Treves, recorded the phenomenon with an ergograph and described troclea (as he first called the sign) as "a muscular undulation, particularly evident at the triceps brachii, through the skin, that initiates with the movements of flexion and extension, both passive and active"11. They published an observation on the cogwheel phenomenon in the Archives Italiennes de Biologie in 1901, in French, after having presented it at the Fifth International Congress of Physiology, held in Turin in September $1901^{11}$. A summary of the paper was also reported one year later in the German journal Neurologisches Centralblatt ${ }^{9,11,12}$. In 1907, Negro published a second article on this phenomenon, which he called troclea or ruota dentate, and noted that the "cogwheel phenomenon, found in all forms of paralysis agitans and usually present at the onset of the disease, is an important clinical finding for an early diagnosis of this disorder ${ }^{9,11,12}$. Negro's sign, which can be observed in peripheral facial paralysis and in which the eyeball on the paralyzed side deviates outward and rises more than the normal eyeball when the patient raises his eyes, was also described by him ${ }^{2,10}$.

\section{NEGRO AND SCIENTIFIC CINEMA}

Camillo Negro was also a pioneer of scientific cinema. From 1906 to 1908, working with his assistant Giuseppe Roasenda and in collaboration with Roberto Omegna, one of Italy's most experienced cinematographers, he filmed a number of his patients for scientific and educational purposes. The resulting work, known as La Neuropatologia, comprised 24 short films, the main aim of which was to document cases with neurological signs so that the principal signs and characteristics of nervous diseases such as hysteria, paralysis agitans, epileptic seizures, tics, pathological gait, paralysis of the eye muscles and other forms of neurasthenia could be reproduced on the screen ${ }^{2}$. The first public screening of a selection of the films took place at the 
Ambrosio Biograph cinema in Turin on February 17, 1908, in the presence of members of the Royal Academy of Medicine in Italy. On April 11 of the same year, it was shown at the first inaugural meeting of the Italian Neurology Society. During World War I, in his work at the Turin Military Hospital, Negro also filmed several cases of "war neurology”, including muscular disturbances, war wounds and cases of mental disorders now called "post-traumatic stress disorder" ${ }^{1,2}$. Recently, in 2011, these films were restored by the National Cinema Museum and the Department of Neurosciences at the University of Turin (Professor Adriano Chiò). In addition to making many contributions to neurology, Negro pioneered the use of cinematography in teaching and the study of nervous diseases ${ }^{2}$.

\section{References}

1. Chiò A, Gianetto C, Dagna S. Professor Camillo Negro's Neuropathological Films. J Hist Neurosci. 2016;25(1):39-50. https://doi.org/10.1080/0964704X.2015.1070034

2. Schettini L. NEGRO, Camillo. In: Dizionario biográfico. Treccani. it; 2013 [cited 2018 Nov 2]. Available from: http://www.treccani.it/ enciclopedia/camillo-negro(Dizionario-Biografico)/

3. Teive HA. Neurological examination: history, problems and facts in the 21st century. Arq Neuropsiquiatr. 2015 Feb;73(2):77-8. https://doi.org/10.1590/0004-282X20140241

4. Steinmetz H. A Short history of neurology in Germany: the first 150 years in 2500 words. Deutsche Gesenllschaft für Neurologie - DGN. [cited 2018 Nov 2]. Available from: https://www.dgn.org/rubrik-dgn/3080-a-shorthistory-of-neurology-in-germany-the-first-150-years-in2500-words

5. Negro C. Patologia e clinica del sistema nervoso: lezioni del Prof. Camillo Negro. Torino: Lattes; 1913.
6. Teive HA, Munhoz RP, Lees AJ. Parkinson's disease - 200 years: the outstanding contribution of "Old Hubert". Arq Neuropsiquiatr. 2017 Mar;75(3):192-4. https://doi.org/10.1590/0004-282×20170006

7. Goetz CG. Charcot on Parkinson's disease. Mov Disord. 1986;1(1):27-32. https://doi.org/10.1002/mds.870010104

8. Teive HA. [Charcot's contribution to Parkinson's disease]. Arq Neuropsiquiatr. 1998 Mar;56(1):141-5. Portuguese. https://doi.org/10.1590/S0004-282X1998000100026

9. Ghiglione P, Mutani R, Chiò A. Cogwheel rigidity. Arch Neurol. 2005 May;62(5):828-30. https://doi.org/10.1001/archneur.62.5.828

10. Campbell WW. De Jong's. The neurological examination. 7th ed. Philadelphia, USA: Lippincott Williams \& Wilkins; 2012.

11. Negro C, Treves Z. Physiopathologie de La contraction musculaire volontaire (maladie de Parkinson). Arch Ital Biol. 1901;26:121-3.

12. Negro C. Il cosiddetto fenomeno della "troclea dentata" nelle forme Parkinsoniane di mogigrafia spastica. Riv Neuropatol. 1907; 2:181-2. 